\title{
Narratives of historial urban lakefront regenerations
}

\author{
Pallavi Dalal ${ }^{1}$, Sunita Kothari ${ }^{2}$ \\ ${ }^{1}$ Baliram Hiray College of Architecture,Kherwadi,Bandra,Mumbai,India \\ ${ }^{2}$ Asmita College of Architecture,Mira Road,Mumbai,India.
}

\begin{abstract}
Lakefront in the densely populated area is a place of relish, where people can enjoy and relax. As these kinds of areas are famous in urban context to provide ample visual and physical public access to water and land. The immediate alliance between settlement and water is inherent since decades, as many urban areas in the world located near to the waterfront. All these areas are directly or indirectly dependent on water for their day to day survival. Since last two decades development strategies are shifting from agriculture to industrial, these bring extensive changes in lakefront development. In precise, lakefront has become less significant for human life. This paper discusses the extensive phenomenon of lakefront development in Thane city, which is known as the "City of Lakes", because of manifold lakes found over there. At present most of the lakes present in city are at the verge of disappearance due to reckless development. Therefore it is necessary to emphasize at historical and social aspect of lakes taking into account the overall picture and presenting the opportunities to integrate and emphasize multidisciplinary approach with social and cultural life of people.
\end{abstract}

\section{Introduction}

Water is an element that is essential for both life and life threatening. The dual force within water represents the essence of Yin and Yang. Where good can't exist without evil (Toy 7) Human survival without water is unjustifiable and without the presence of water any human settlement can't exists. This implicit that water is integral factor of selection of site for human settlement. In fact microlocation of presence of water also shows positive aspects for human settlement in history.

For generating good aesthetic quality or representing the visual image of city or city's skyline water plays an important role. Which enhances the city's silhouettes, urban matrix and it provides scope for better future expansion. Water front provides strong base line for urban development and gives better opportunities for physical and visual connection of city and its people with water. City like Chicago or holy cities such as Banaras gives opportunities and dependence of water related structures to people. Water can even impact human activities physically, socially and even psychologically. As Cities water phenomenon defines cities growth shape and inheritance of human settlement.

In time human needs become more variants or complex with the change in social, economic and technological needs, it gives an number of options for collecting or disrupting water for human needs, This leads to exploitation of water sources. Furthermore, it defines the means of communication as well as micro endeavours in planning of some of the important infrastructural intervention in the cities development. For example, In Mumbai, Marine drive's Queens Necklace and Bandra's Bandstand areas defines water edge as well as building skyline.

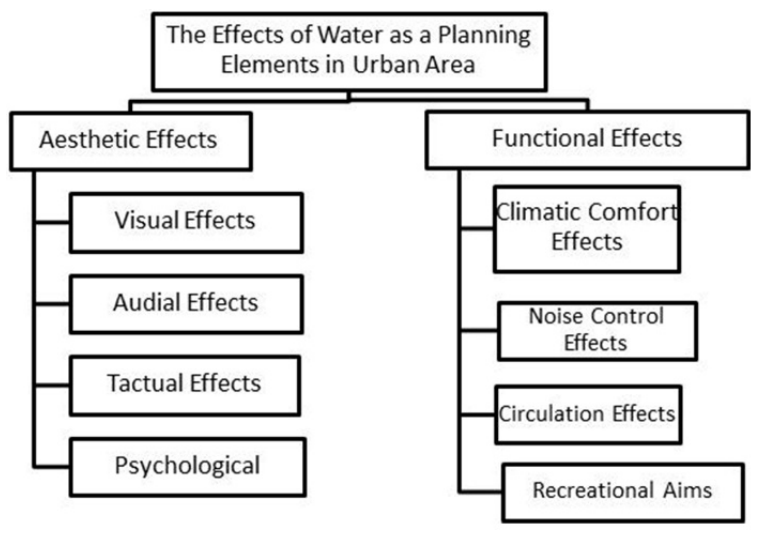

Fig.1. Adopted from Onen (2007), the effects of water as a planning element in Urban Area.

\subsection{Pattern of Waterfront development-}

In some of the recent decades, many waterfront cities or towns are facing an immense pressure of development from brownfield to large urban areas. As throughout the history the relationship between water and urban settlement is intact, it provides absolute living areas for human being. Such as in case of India, Banaras- Sacred 
place located on the western bank of the Ganga River, where many sacred activities are closely associated with the water. It shows the close relationship between human being and water.

In the contemporary era, many cities or towns in America, Europe and Asian countries are settled near the waterfront or on the bank of waterfront. In Mumbai Eastern waterfronts has historically been the hub of transportation, trade and commerce since early 19th centuries.

Therefore, major part of eastern edge is always inaccessible for common people. Which shows every urban waterfront has its own history, always tends to change as per the real estate impact, political scenario, physical and social needs of cities and people.

\begin{tabular}{|c|c|c|}
\hline $\begin{array}{c}\text { In location with } \\
\text { water }\end{array}$ & \multicolumn{2}{|c|}{ Urban Waterfronts } \\
\hline $\begin{array}{c}\text { Symbolizes Coastal } \\
\text { Cities }\end{array}$ & On Peninsula & On Bay \\
\hline $\begin{array}{c}\text { Symbolizes Inland } \\
\text { ones }\end{array}$ & $\begin{array}{l}\text { On banks of } \\
\text { River }\end{array}$ & $\begin{array}{c}\text { On a large body } \\
\text { of water }\end{array}$ \\
\hline
\end{tabular}

Fig 2: Water as a planning element in Urban Area

Cities which are located on peninsulas, bay, gulf, river, estuaries and deltas gets large area to deal with waterfront activities.

\subsection{Typical pattern of waterfront development}

Throughout history, waterfronts are the most ideal living area for human beings to be able to provide food, settling, reproduction, defence and learning etc. So, the many cities or towns Urban Waterfront Regenerations are established over water's edge from the history of civilization to until today.

In the contemporary era, the many cities or towns in America, Europe and Asian countries such as India, Singapore and China can be given as examples of waterfront settlement. In Mumbai, Eastern waterfronts has historically been the hub of transportation, trade and commerce since early $19^{\text {th }}$ century .Therefore, major part of eastern edge were always inaccessible for common people. Thus, every urban waterfront has its own history which always tends to change as per the real estate impact, political scenario, physical and social needs of cities and people.
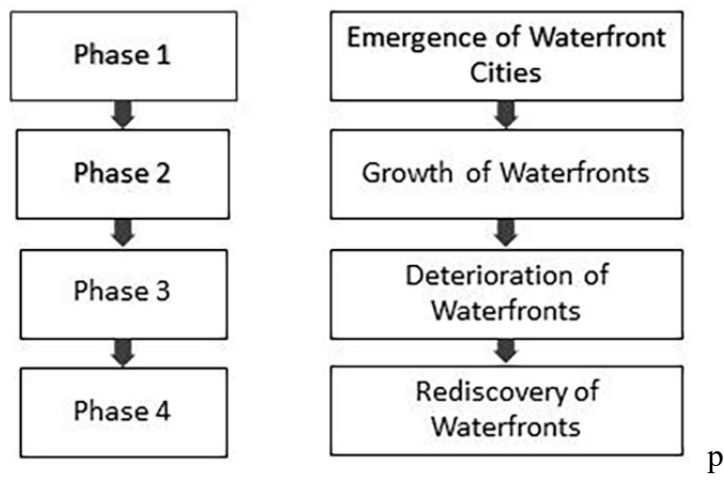

Fig.3.Adated from Wrenn et.al. 1983, Typical pattern of waterfront development phases.

\section{Need of the Waterfront development}

In last few decades because of the pace of urbanization and industrialization, many cities along the waterfronts are facing the issues of development. As areas around the waterfronts are in absolute degraded condition. Which even do not allow the access for recreation or open spaces around the water edge.

Pleasant water edge with minimum standards of recreational activities can provide boost or can attract, high investment and can motivate people to restrain which is being lost in the process of urbanization.

\subsection{Waterfront development-a case of Chicago}

The city Chicago- known for its skyline as well as its water edge development, is not as clean as it has seems today. In early 20th century it was the dump yard, the waste was directly discharged into either Lake Michigan or the river which flowed into the lake. As the solution to this situation they decided to reverse the flow of river and they build Chicago sanitary ship canal. Architect Daniel Burham proposed straightening of river channel, along with the 08 parks, the main branch runs through the heart of the city and it provides space for recreational activities, river walk and linkage with other places. . Strong emphasis on quality, functionality and sense of place.

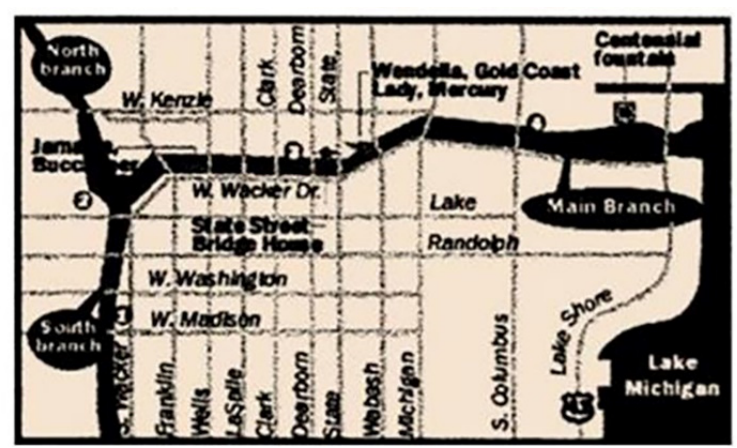

Fig.4.River walk plan showing various branches 
Chicago Riverfront is examined and analysis under the urban design dimensions mentioned by Carmona, Heath, Oc and Tiesdell (2005)

Conclusion- It has been a successful place in its diversity for development and waterfront edge. It has provided a great example of waterfront development within in city.

\section{Case of Thane city}

The Thane is one of the Maharashtra's metropolitan city. As per national becemial census 2011 the population of the city is 11060148 . This is the fastest growing city abutting to Mumbai. As the Mumbai has almost reaching to it carrying capacity of development, Thane is the one of the most favourable option for people as housing requirement. Which is already been looked up. The Thane city infrastructure and growth of the residential sector has given multi-facet to city's face. The geographical jurisdiction of the Thane city spreads over the area of 128.23 sq.mt. the city is called as "City of Lakes" as it comprise of 35 lakes in an area of 40 hector.The ancient Thane (Thana) is said to be derived from "Sthan". The capital of Silahara Kings of Kokan.Thane city has rich cultural heritage, mythological background and has been home to many events of historical importance. Thane city can be broadly categorized into 5 eras.

- Vedic period to 1300. : Comprising of Hindu or ancient period, Apparent, Shilhara and Bimba dynasties. 1300 1737: Muslim and Portuguese rule.

- 1737-1800: Maratha and Portuguese rule.

- 1800-1947: British Rule. 1947-till date: Independent India.

- $\quad$ The Shilharas ruled Thane from 810 to 1260 .

During the 17th century place called Ghodbander was very famous for trading of horses. The Silahara emperors were disciples of Lord Shiva and they built Kopineshwar Temple during their rein. In all culture and religion water has always given a high spiritual importance and also utilized for recreational activities. Similarly, in ancient period these Thane lakes were integral part of such activities. However, over the period due to housing and infrastructure development pressure, these lakes have lost its originality and importance.

\subsection{Need of conservation of lakefront}

The principal images of Thane are triggered as a cultural centre, as well as for lakes. Earlier, Thane had more than 60 lakes, as eminent town planner Patric Geddes called it rightly as "City of Lakes". However today only 15 are remaining which are deteriorating or encroached upon and just occur incidentally while moving through the city. They are not maintained and are getting reclaimed slowly turning into city dump or wastewater collection ponds perhaps waiting for an epidemic.
Table 1.showing elements of urban design and its implementation.

\begin{tabular}{|c|c|c|}
\hline $\begin{array}{l}\text { The Dimension } \\
\text { of Urban Design }\end{array}$ & Elements & Comments \\
\hline $\begin{array}{l}\text { Morphological } \\
\text { dimension }\end{array}$ & $\begin{array}{l}\text { Land use } \\
\text { Building } \\
\text { structure } \\
\text { Plot pattern } \\
\text { Street pattern }\end{array}$ & $\begin{array}{l}\text { Good } \\
\text { connection with } \\
\text { the rest of the } \\
\text { Chicago City. } \\
\text { It has good } \\
\text { mixed land use. }\end{array}$ \\
\hline $\begin{array}{l}\text { Perceptual } \\
\text { Dimension }\end{array}$ & $\begin{array}{l}\text { Sense of place } \\
\text { Meaning and } \\
\text { symbolism' } \\
\text { Image of the city }\end{array}$ & $\begin{array}{l}\text { It form a small } \\
\text { community } \\
\text { within the site } \\
\text { and has created } \\
\text { a sense of place }\end{array}$ \\
\hline $\begin{array}{l}\text { Social } \\
\text { dimension }\end{array}$ & $\begin{array}{l}\text { People and space } \\
\text { Public realm } \\
\text { Safety } \\
\text { Neighbourhood } \\
\text { Accessibility, } \\
\text { disability and } \\
\text { exclusion }\end{array}$ & $\begin{array}{l}\text { High quality of } \\
\text { realm }\end{array}$ \\
\hline $\begin{array}{l}\text { Visual } \\
\text { dimension }\end{array}$ & $\begin{array}{l}\text { Aesthetic } \\
\text { preference } \\
\text { Building and } \\
\text { architectural } \\
\text { Amenity- } \\
\text { footpath layout } \\
\text { Landscaping }\end{array}$ & $\begin{array}{l}\text { Good use of } \\
\text { lighting and path } \\
\text { layout }\end{array}$ \\
\hline $\begin{array}{l}\text { Visual } \\
\text { dimension }\end{array}$ & $\begin{array}{l}\text { Aesthetic } \\
\text { preference } \\
\text { Building and } \\
\text { architectural } \\
\text { Amenity- } \\
\text { footpath layout } \\
\text { Landscaping }\end{array}$ & $\begin{array}{l}\text { Good use of } \\
\text { lighting and path } \\
\text { layout }\end{array}$ \\
\hline
\end{tabular}

Today it's difficult to call Thane a city of lakes. Is there a way to regain the ineffable quality of a city with lakes and how does one go about achieving it in the present situation is the question. 

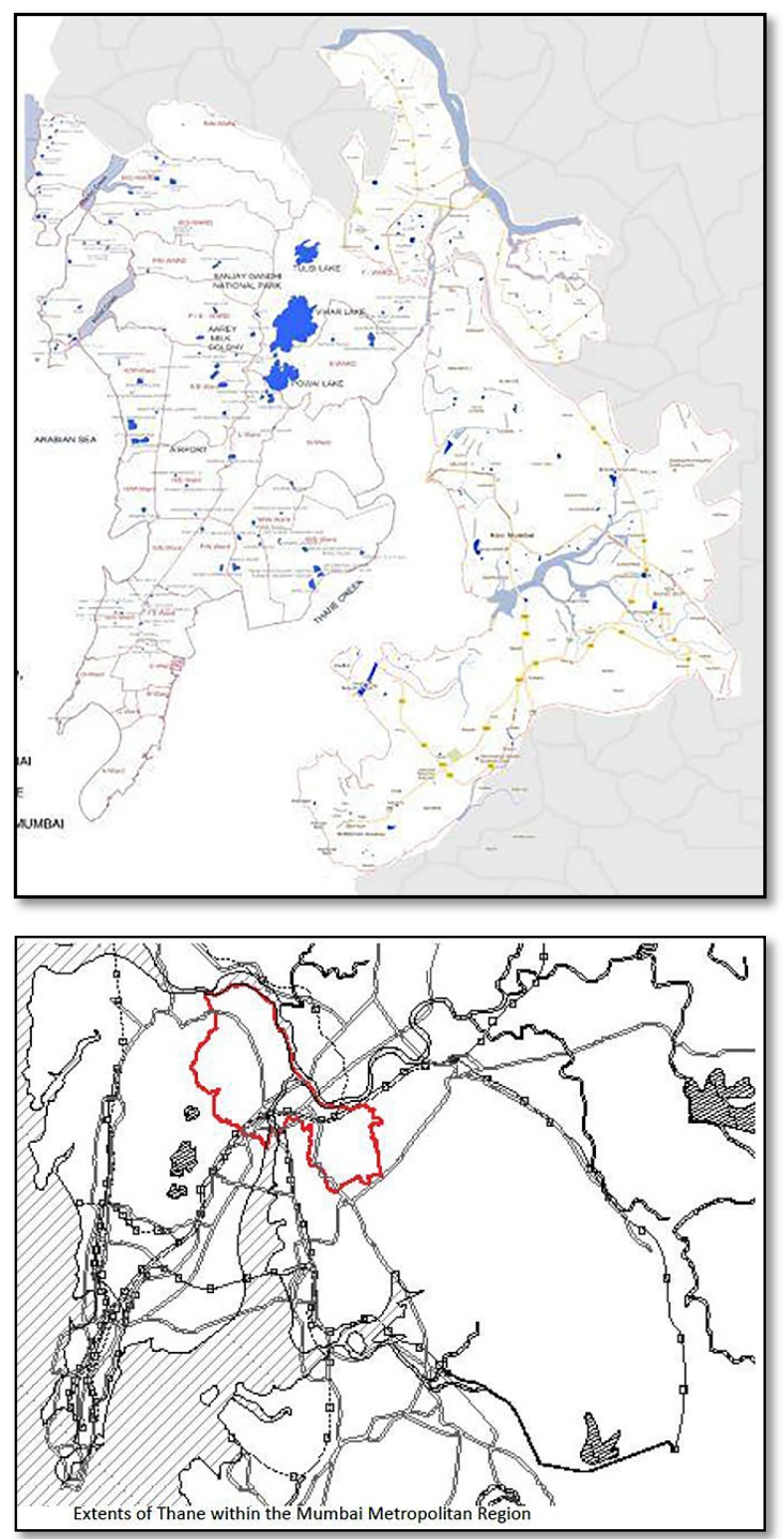

Fig.5. Map showing the location of water bodies in the city of Thane.

As population of Thane grows, this lakefront are becoming a dumping places.in last few decades population of thane is growing in tremendous way, as many other infrastructural development is becoming main part of urbanization in the society.as Thane is establishing good connectivity with other parts of Mumbai city, residential development as taken as boom.

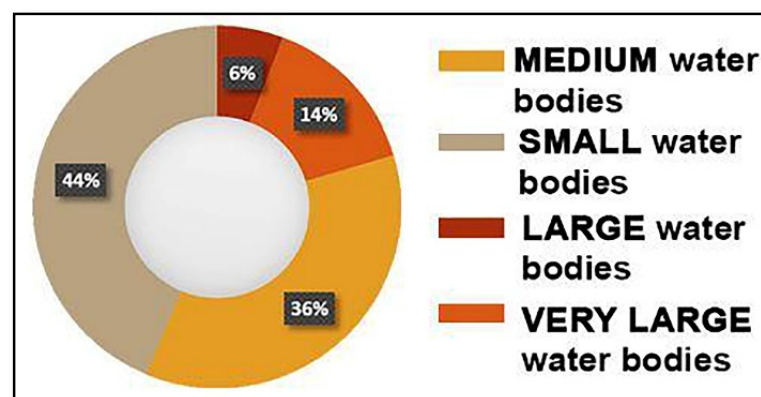

There are around 103 water bodies in mumbai, 38 water bodies in thane and 46 water bodies in navi mumbai.

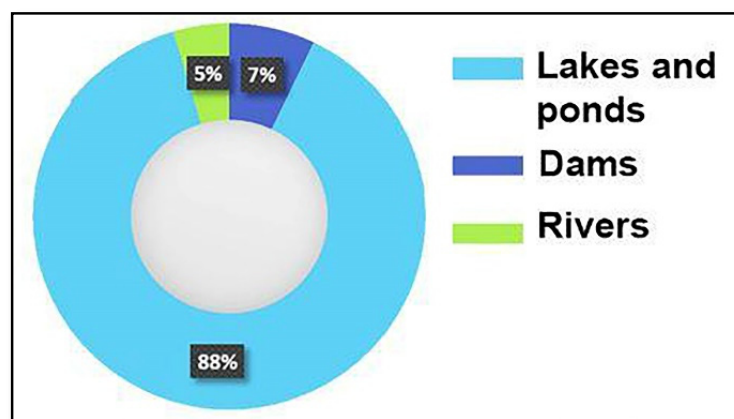

Even though thane is called the city of lakes and the comparative percent of lakes is more, only $4.29 \%$ lakes exists in thane.

Fig.6. Pie chart showing the percentage of water bodies around the city.

There are around 103 water bodies in Mumbai, 34 water bodies in Thane and 46 water bodies in Navi Mumbai. In city of Thane, total number of lakes register by TMC(Thane Municipal Corporation)are 34, out of which only 9 lakes are conserves or having good public facilies.as urban growth increases the percentage of water bodies as well as open spaces is getting reduced.as per WHO norms of open spaces is required per person. But because of pace of urbanization and industrialization in the city of Thane per person open spaces percentage is reduced.

Downtown of Thane consisted of five major water bodies in close proximity to each other, which are having same peculiar charter and similar developmental problems.

By studying the downtown of Thane city and having done surveys for the same, we came to know that these spaces can be act as breathing spaces for the communities surrounding that. $2 \mathrm{~km}$ radius, which are connected via roads or pedestrian movement within the settlement. 


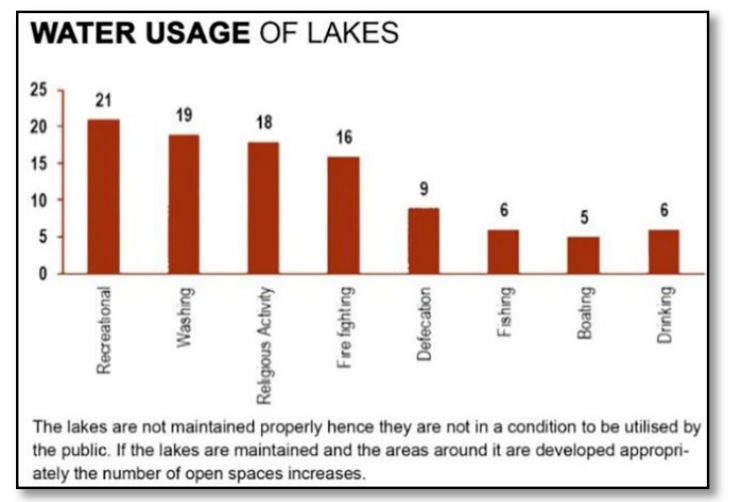

Fig.7. Percentage of water usage of lakes for different activities.

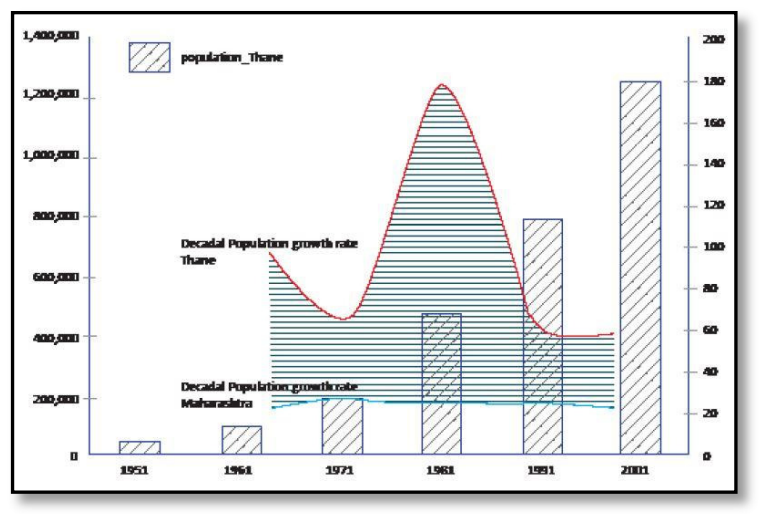

Fig.8. Graph showing population growth rate of Thane city.

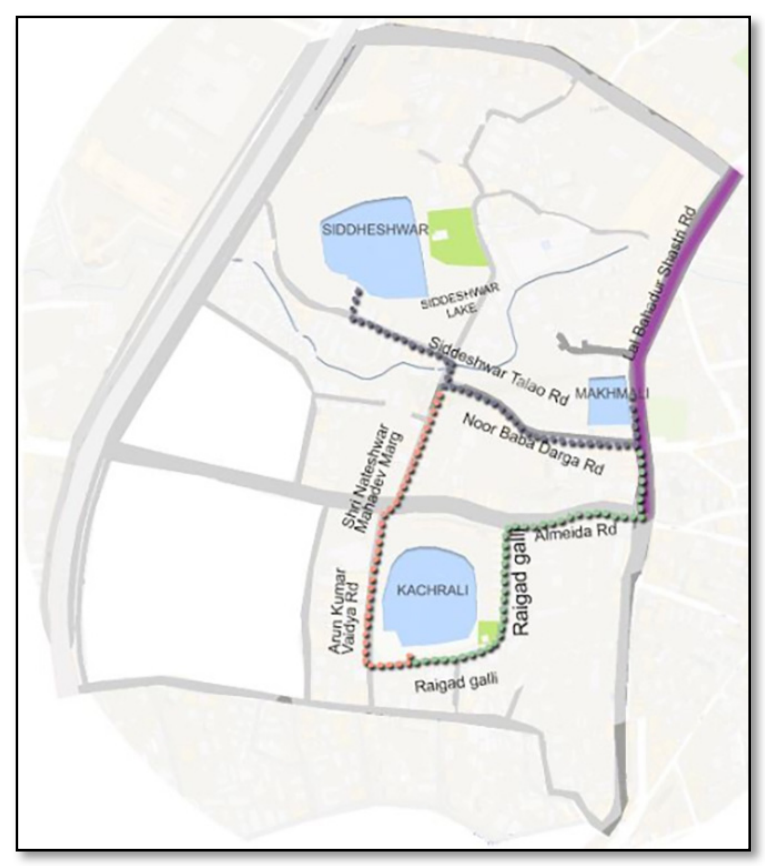

Fig.11. Map showing vicinity area of 3 lakes, which can reconnect to form network.
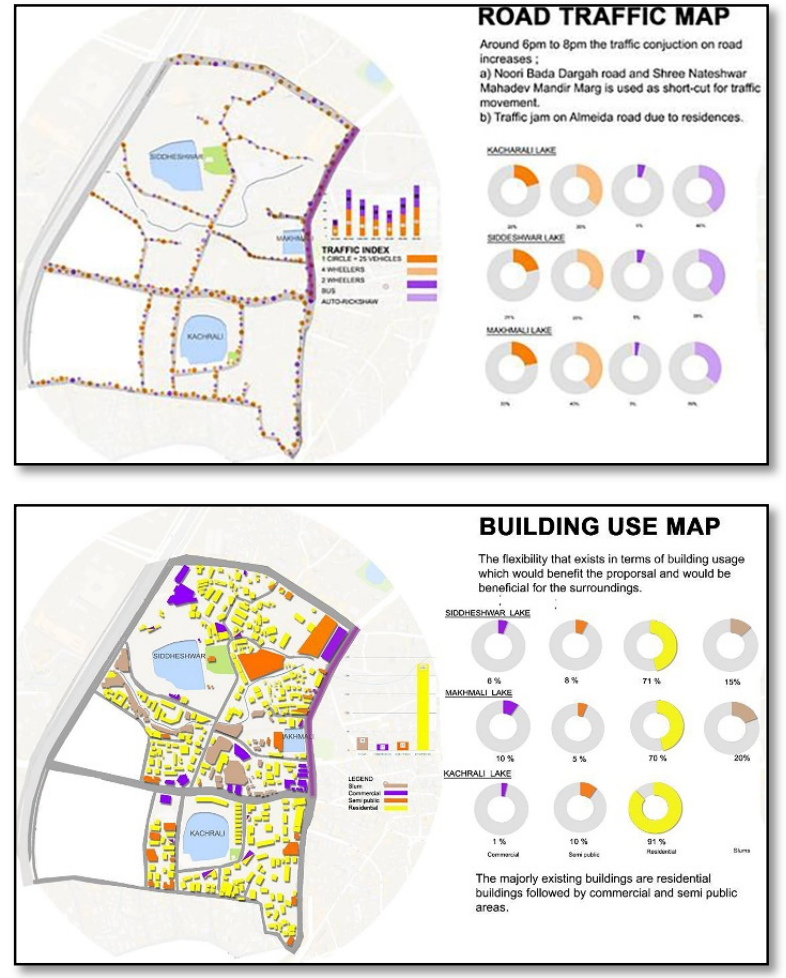

Fig.9\&10. Map showing Road traffic map \& Building use map. Out of five lakes, three lakes are within the periphery.

\subsection{Survey findings-}

- This route has been extensively used by passers-by as a short-cut from major roads, which increases the traffic movement in pick timings.

- The areas around this lake, has been encroached by slum dwellers resulting into unhealthy condition and reducing the water levels.

- The hawkers has been encroached on the footpaths resulting in to garbage littering.

- Illegal encroachment on roads and around the lakes making lakes smaller and decreasing the water level in the lakes.

As all of this survey findings point out towards the encroachment and negligence of the people surrounds the water body. This shows people are less interested in the areas which are not providing them any kind of activities or attractions.

\section{Conclusion -}

Rapidly growing city like 'Thane' the foremost challenge is to plan the city's growth in right direction and to improve the quality of water edges and its surrounding environment. Where lakeside land or surroundings can be utilize very carefully 
to improve the quality of life for close association between water people can be establish by using different activities as well as applying intervention and to create awareness among the people.

\section{References}

1) U. P. Timur, Urban Waterfront Regenerations, (2013)

2) D. M. Wrenn, Urban Waterfront Development, (1983)

3) G O. Moretti, M., TeMaLab Jrnl, of Mobility, 3, 57, (2010)

4) Hussein, R.M.R., Int. Jnl. of Civil, Env. Struc. Engg., 8, 488, (2014)

5) S. Barve, S. Sen., WITPRESS LTD., (2011) 